APMA

Jurnal Pengabdian Masyarakat
Volume 1 Nomor 2 Juli 2021

http://jurnal.bhmm.ac.id/index.php/apma/ DOI: 10.47575/apma.v1i2.256

\title{
Meningkatkan Pengetahuan Siswa Tentang Jajanan Sehat
}

\author{
* Mega Arianti Putri \& Fitria Yuliana \\ Sekolah Tinggi Ilmu Kesehatan Bhakti Husada Mulia Madiun, Indonesia
}

\begin{abstract}
ABSTRAK
Pertumbuhan dan perkembangan anak usia sekolah harus optimal seperti pemberian nutrisi dengan kualitas dan kuantitas yang baik serta benar, bila tidak benar dapat mengakibatkan gangguan pada banyak organ tubuh anak usia sekolah. Memasuki usia sekolah, anak mulai ingin menunjukkan kemampuannya menentukan pilihan atas makanan. Cara yang dapat dilakukan adalah dengan promosi kesehatan mengenai jajanan sehat dan bahaya junk food. Kegiatan pengabdian kepada masyarakat ini dimaksudkan kepada siswa untuk mengurangi paparan anak sekolah terhadap makanan jajanan yang tidak sehat dan tidak aman. Kegiatan pengabdian ini dilaksanakan dengan metode sebagai berikut: a).Metode ceramah, digunakan untuk menyampaikan pengetahuan tentang jajanan sehat dan bergizi meliputi: Unsur gizi dalam makanan dan bahan tambahan makanan. b). Metode praktek, digunakan untuk simulasi membandingkan 2 macam jajanan yang biasa dikonsumsi,secara berkelompok dengan setiap kelompok beranggotakan 5 orang anak. c).Metode tanya jawab, digunakan untuk memberikan tanggapan kepada siswa sekaligus untuk mendapatkan tanggapan siswa tentang materi yang telah disampaikan selama kegiatan. Antusias siswa pada saat pelaksanaan penyuluhan sangat tinggi, dibuktikan dengan semua siswa mengerjakan pretes. Pada saat proses penyampaian materi, siswa juga bisa diajak interaksi, dengan mengajukan beberapa pertanyaan dari materi yang telah disampaikan. Hasil pretes rata-rata sebesar 77,68 dan rata-rata postes sebesar 85,69. Hasil penghitungan nilai menunjukkan pengetahuan jajanan sehat siswa meningkat dengan kategori sedang. Siswa dapat membedakan jenis makanan sehat dan tidak sehat serta mengetahui dampak dari jajanan sehat setelah dikonsumsi. Kesimpulan dari kegiatan ini adalah: (1) Antusias siswa sangat tinggi, semua siswa mengikuti kegiatan mulai dari awal sampai akhir; (2) Pengetahuan siswa tentang jajanan sehat meningkat. Saran dari kegiatan pengabdian ini adalah pengabdian ini dapat dilakukan di sekolah lain dengan melibatkan guru serta orang tua, agar pengawsan nutrisi yang didapatkan anak bisa lebih baik.
\end{abstract}

Kata kunci: Jajanan Sehat, Pengetahuan, Anak sekolah. 


\section{PENDAHULUAN}

Gizi merupakan hal yang amat penting dalam pertumbuhan serta perkembangan fisik dan mental anak. Menurut Devi (2012), gizi kurang dapat terjadi karena kekurangan zat gizi makro seperti energi, protein, lemak dan dapat pula karena kekurangan zat gizi mikro seperti vitamin A, besi, yodium dan seng. Kekurangan ini disebabkan kurangnya asupan sumber zat gizi yang dibutuhkan anak, anak tidak mengonsumsi gizi seimbang, tidak sarapan dan jajanan yang tidak sehat. Makanan jajanan memegang peranan yang cukup penting dalam memberikan asupan energi dan zat gizi lain bagi anak-anak usia sekolah. Konsumsi makanan jajanan anak sekolah perlu diperhatikan karena aktivitas anak yang tinggi. Konsumsi makanan jajanan anak diharapkan dapat memberikan kontribusi energi dan zat gizi lain yang berguna untuk pertumbuhan anak (Sutardji, 2007).

Memasuki usia sekolah, anak mulai ingin menunjukkan kemampuannya menentukan pilihan atas makanan. Anak sekolah belum mengerti cara memilih jajanan yang sehat sehingga berakibat buruk pada kesehatannya sendiri (Suci, 2009). Anak membeli jajan menurut kesukaan mereka sendiri tanpa memikirkan bahan-bahan yang terkandung didalamnya (Judarwanto, 2008). Anak sekolah biasanya mempunyai lebih banyak aktivitas di luar rumah dan sering melupakan waktu makan sehingga mereka membeli jajanan di sekolah untuk mengganjal perut (Rakhmawati, 2009). Melihat banyaknya pilihan jajanan dalam kemasan, anak mulai tidak mudah lagi diatur dengan makanan yang biasa disediakan orang tua di rumah. Sejalan dengan itu, gizi anak sekolah sering terabaikan, karena orang tua beranggapan anak sudah besar dan mampu memilih jajanan sendiri. Kebiasaan jajan ini dipengaruhi oleh faktor jenis makanan, karakteristik personal (pengetahuan tentang jajanan, kecerdasan, persepsi, dan emosi), dan faktor lingkungan (Ariandani, 2011). Sibagariang (2010) menyebutkan, lingkungan yang kurang baik juga dapat mempengaruhi gizi pada anak, sebagai contoh seringnya anak jajan sembarangan di tepi jalan, karena melihat teman-temannya yang juga sedang jajan sembarangan. Kurangnya pengetahuan tentang gizi menjadikan anak membeli makanan tanpa tahu apakah makanan tersebut mengandung gizi cukup atau tidak.

Pengetahuan jajanan sehat sangat berpengaruh terhadap cara atau perilaku anak dalam menentukan jenis pilihan makanan yang mereka konsumsi. Kegiatan pengabdian ini memiliki tujuan meningkatkan pemahaman tentang konsumsi jajanan sehat bagi siswa TK Mojorejo. Sesuai permasalahan yang telah diuraikan di atas, maka meningkatkan pemahaman tentang jajanan sehat dengan memperhatikan kandungan gizi menjadi solusi yang tepat, agar anak dapat memilih jajanan yang bergizi dan sehat. Melalui pengabdian ini anak dilatih untuk memilih jajanan sehat, bergizi dan aman. Diharapkan anak bisa menceritakan kepada orang tua tentang pengetahuannya, dan tidak sembarangan dalam memilih jajanan dalam kemasan.

\section{METODE}

Kegiatan pengabdian ini berlangsung dalam tahapan-tahapan, meliputi: 
a. Tahap persiapan, pada tahap ini dilakukan persiapan mengenai pembagian tugas anggota tim penyuluhan agar semaksimal mungkin dapat menyampaikan informasi dan pemahaman yang memadai bagi siswa/peserta penyuluhan. Selanjutnya mencari referensi untuk penyusunan materi yang harus disampaikan kepada peserta, menyusun instrument untuk pretes dan postes, menyusun lembar kerja untuk kegiatan praktek. Pada tahap ini juga digunakan untuk menyusun daftar hadir peserta, menyiapkan alat bahan untuk pelaksanaan kegiatan

b. Tahap observasi, pada tahap ini dilakukan konsultasi dengan pihak sekolah tentang faktor-faktor yang mendukung dan menghambat pelaksanaan kegiatan penyuluhan, sehingga dapat dicarikan solusi atau alternatif terbaik dalam pelaksanaan kegiatan. TK Mojorejo terletak di Kecamatan Kawedanan Kabupaten Madiun. Hasil observasi pertama diperoleh informasi sebagai berikut, dalam situasi pandemi Covid-19, TK Mojorejo juga menjalankan protokol kesehatan sesuai anjuran dinas pendidikan Kabupaten Madiun. Proses pembelajaran hanya dilakukan dalam kelompok kecil di rumah siswa, yang dikunjungi oleh guru dan hanya gurunya yang boleh mendatangi kelompok tersebut. Aturan ini berlaku hingga tanggal 14 September 2020. Oleh karena itu, tim pengabdian belum bisa melaksanakan kegiatan pengabdian ini dan harus kembali ke Sekolah tanggal 17 September 2020, memastikan bagaimana pelaksanaan pengabdian ini, mencari solusi dengan mempertimbangkan hasil konsultasi dengan dinas pendidikan TK Mojorejo. Akhirnya disepakati pelaksanaan pengabdian pada tanggal 23 September 2020.

c. Tahap pelaksanaan kegiatan, pada tahap ini kami menyampaikan materi tentang jajanan sehat kepada siswa. Waktu pelaksanaan disesuaikan dengan kesepakatan antara anggota tim pengabdian dengan pihak sekolah tempat sasaran kegiatan. Urutan pelaksanaan kegiatan pengabdian ini adalah Tim pengabdian memperkenalkan diri dan menyampaikan tujuan pengabdian ini. Siswa mengisi daftar hadir, dan mengerjakan tes awal (pretes). Siswa dibagi menjadi 5 kelompok masing-masing kelompok terdiri dari 4-5 orang. Selanjutnya penyampaian materi oleh tim pengabdian,setelah itu peserta melakukan praktek identifikas jajanan sehat, dan menyampaikan hasil identifikasinya di depan kelas diwakili beberapa kelompok. Pada tahap akhir peserta mengerjakan tes (postes) sesudah penyampaian materi.

Kegiatan pengabdian ini dilaksanakan dengan metode sebagai berikut:

a. Metode ceramah, digunakan untuk menyampaikan pengetahuan tentang jajanan sehat dan bergizi meliputi: Unsur gizi dalam makanan dan bahan tambahan makanan. Penyampaian ini dilakukan dengan memberikan contoh konkret, menyediakan contoh jenis makanan

b. Metode praktek/simulasi, digunakan untuk membandingkan secara langsung 2 macam jajanan yang biasa dikonsumsi. Praktek ini dilakukan secara berkelompok dengan setiap kelompok beranggotakan 5 orang anak. Masing-masing kelompok bertugas mengidentifikasi Jajanan sehat dan 
tidak sehat Selanjutnya peserta diminta untuk menceritakan jajanan mana yang lebih baik untuk dikonsumsi.

c. Metode tanya jawab, digunakan untuk memberikan umpan balik pada peserta sekaligus untuk mendapatkan tanggapan peserta tentang materi yang telah disampaikan selama kegiatan.

\section{HASIL DAN PEMBAHASAN}

Kegiatan pengabdian pada masyarakat ini dapat berjalan lancar, berkat dukungan dari pihak sekolah, yang memberikan kesempatan tim melaksanaakan pengabdian. Antusias siswa pada saat pelaksanaan kegiatan sangat tinggi, terlihat pada waktu pretes semua peserta mengerjakan dengan sungguhsungguh. Selanjutnya ketika penyampaian materi, peserta juga dapat diajak interaksi, dengan mengajukan pertanyaan dari materi yang disampaikan. Ketika kegiatan praktek mengidentifikasi dan memilah mana jajanan yang aman dan sehat untuk dikonsumsi, semua kelompok antusias dan bersungguh-sungguh mengerjakan tugas yang diberikan. Mereka ingin menjadi yang nomer satu, ketika diminta membacakan hasil kerja kelompoknya. Antusias mereka juga terlihat ketika mengerjakan postes, semua mengerjakan dengan sungguhsungguh dan bekerja sendiri-sendiri, sehingga situasi tidak gaduh.

Rata-rata hasil evaluasi yang dilakukan sebelum penyampaian materi (pretes) sebesar 77,68 dan rata-rata hasil tes setelah diberikan materi (postes) sebesar 85,69. Hal ini membuktikan bahwa pengetahuan jajanan sehat peserta (siswa) meningkat dengan kategori sedang. Siswa dapat memilah jajan yang baik dikonsumsi ketika membeli jajanan.

Kegiatan pengabdian ini melatih anak untuk memilih jajanan sehat, bergizi dan aman. Diharapkan anak bisa menceritakan kepada orang tua tentang pengetahuannya, dan tidak sembarangan dalam memilih jajanan dalam kemasan.Kebiasaann anak mengkonsumsi jajanan sembarangan disebabkan ketidaktahuan tentang fungsi zat gizi bagi tubuh. Ketidaktahuan akan gizi yang baik pada anak menyebabkan anak sering berperilaku salahdalam mengonsumsi zat gizi. Berikut beberapa perilaku gizi yang salah pada anak sekolah (Devi, 2012): a) Tidak mengonsumsi menu gizi yang seimbang, menu gizi yang seimbang seharusnya menjadi pedoman bagi pola makan anak sekolah. (b) Tidak sarapan pagi, makan pagi mempunyai peranan penting bagi anak sekolah usia 6-14 tahun, yaitu untuk pemenuhan gizi di pagi hari di mana anak-anak berangkat ke sekolah dan mempunyai aktivitas yang sangat padat di sekolah, (c) Jajan tidak sehat di sekolah, anak sekolah tidak bisa terlepas dari makanan jajanan di sekolah, (d) Kurang mengonsumsi buah dan sayur, buah dan sayur merupakan sumber zat gizi vitamin dan mineral, (e) Mengonsumsi fast fooddan junk food,fast foot adalah istilah yang diberikan untuk makanan yang dapat disusun dan disajikan dengan cepat. Sedangkan junk foodmendiskripsikan makanan tidak sehat atau memiliki sedikit mengandung kandungan nutrisi, (e) Mengonsumsi makanan berisiko, yang termasuk makanan yang berisiko adalah penyedap makanan (MSG), makanan berkafein, makanan yang diberi pengawet, dan bahan pewarna yang dilarang, (f) Konsumsi gula berlebihan, 
gula ditemukan secara alami dalam buah-buahan (fruktosa) dan susu cair dan produk susu (laktosa), (g) Konsumsi lemak berlebihan, lemak makanan terdapat pada tumbuhan dan hewan.

Santosa dan Ranti (2009), menyebutkan fungsi lemak bagi tubuh selain sebagai pemberi kalori, juga sebagai pembentukan membran sel, memberikan asam lemak esensial dan melarutkan vitamin. Sibagariang (2010) menambahkan, fungsi lemak adalah memberi rasa gurih dan renyah pada makanan yang digoreng, memberikan sifat empuk pada kue yang dibakar, pelindung organ tubuh,memelihara suhu tubuhdan sebagai sumber asam lemak tak jenuh.Lemak juga merupakan zat yang digunakan bagi tubuh untuk memproduksi prostaglandin yaitu hormone yang berperan mengatur tekanan darah, system saraf, denyut jantung, kontriksi pembuluh darah, dan pembekuan darah. Lemak juga memelihara kulit, rambut, melindungi organ penting dan memelihara tubuh tetap hangat.

Mengkonsumsi makanan yang berlemak, rasa kenyang yang kita rasakan akan bertahan lebih lama, namun mengonsumsi makanan tinggi lemak memberikan efek buruk bagi kesehatan, meningkatkan resiko terkena jantung coroner, kolesterol darah, diabetes dan beberapa jenis kanker. Obesitas, penyakit batu empedu, liver, osteoarthritis juga dipicu oleh karena konsumsi tinggi lemak. Apabila dalam makanan kita kelebihan karbohidrat atau lemak yang diperlukan tubuh, maka akan diubah menjadi lemak dan disimpan sebagai cadangan tenaga yang sewaktu-waktu diambil jika diperlukan tubuh. Pudjiati (2001) menyebutkan, lemak cadangan disimpan di bawah kulit, di sekitar otot-otot dan alat-alat tubuh yang lain. Kumpulan lemak di sekitar alat tubuh berfungsi untuk menjaga agar alat tubuh tersebut terdapat pada posisinya, misalnya lemak di sekitar rongga mata, yang berguna sebagai bantalan biji mata.

\section{SIMPULAN}

Kesimpulan dari kegiatan ini adalah: (1) Antusias siswa sangat tinggi, semua siswa mengikuti kegiatan dari awal sampai akhir; (2) Pengetahuan siswa tentang jajanan sehat dalam kemasan meningkat, dalam kategori sedang.

\section{UCAPAN TERIMA KASIH}

Penulis mengucapkan terima kasih kepada STIKES Bhakti Husada Mulia yang telah mendukung terlaksananya kegiatan pendidikan kesehatan ini dengan cara memberikan izin. Penulis juga mengucapkan terima kasih kepada kelompok arisan wanita Desa Purworejo Kecamatan Geger Kabupaten Madiun, yang telah mengizinkan dan memberi dukungan kegiatan pengabdian ini. 


\section{DAFTAR PUSTAKA}

Ariandani, B. (2011). Faktor Yang Berhubungan Dengan Pemilihan Makanan Jajanan Pada Anak Sekolah Dasar. http:/ /eprints.undip.ac.id/32606/1/403_Bondika_Ariandani_aprillia_G2C 007016.pdf

Cahyadi., W. (2008). Analisi dan Aspek Kesehatan Bahan Tambahan Manakan. Jakarta. BumiAksara

Depdiknas. (2008). Kurikulum Tingkat Satuan Pendidikan, Jakarta Dikmenum.

Devi, N. (2012). Anak Sekolah. Jakarta. Kompas

Kusmiyati. (2016). Penyuluhan tentang Pemilihan Jajanan Sehat Pada Siswa SDN 1 Tamansari. Laporan pengabdian pada masyarakat, LPPM Unram. Mataram

Hamida, Khairuna., Zulaekah, Siti., Mutalazimah. (2012). Penyuluhan Gizi dengan Media Komik untuk Meningkatkan Pengetahuan tentang Keamanan Makanan Jajanan. Jurnal Kesehatan Masyarakat, 8(1): 67-73

Pudjiati S. (2001). Ilmu Gizi klinis pada anak. Jakarta.

FKUI Peraturan Menteri Kesehatan RI No. 722/MenKes/Per/IX/1988. Bahan Tambahan Makanan

Santosa, S. dan Ranti, A. L. (2009). Kesehatan \& Gizi. Jakarta, Rineka Cipta

Sibagariang, E. E. (2010). Gizi Dalam Kesehatan Reproduksi. Jakarta, Trans Info Media.

Winarno,F.,G., dan Rahayu. (1994). Bahan Tambahan Makanan Untuk Pangandan Kontaminan. Cet 1. Jakarta. Pustaka Sinar Harapan 